\title{
PERBEDAAN HASIL BELAJAR IPA DILIHAT DARI PENGGUNAAN MEDIA KONKRET DENGAN MEDIA AUDIO-VISUAL PADA PESERTA DIDIK KELAS IV SDN-1 PANARUNG PALANGKARAYA
}

\author{
Oleh \\ Desy $^{1}$, Diplan $^{2}$ \\ Email: diplan161181@gmail.com
}

\begin{abstract}
This study aims to determine whether or not there are differences in learning outcomes of science seen from the use of concrete media with audio-visual media in fourth grade students of SDN 1 Panarung 2015/2016 Academic Year. The research method in this study is quantitative correlation. The results of the study show that there are differences in learning outcomes of science seen from the use of concrete media with audio-visual media in fourth grade students of SDN 1 Panarung 2015/2016 Academic Year. with a count of $t$ count of 6.012 and ttable of 2,000 at $\mathrm{N}=59$ with a significant level of $5 \%$ for 2 tails which means tcount $>$ ttable or 6.012>2,000.
\end{abstract}

(C) Muhammadiyah University Palangkaraya

Keywords: Learning Outcomes, Science, Concrete Media, and Audio-Visual Media

\begin{abstract}
ABSTRAK
Penelitian ini bertujuan untuk mengetahui ada atau tidaknya ada perbedaan hasil belajar IPA dilihat dari penggunaan media konkret dengan media audio-visual pada peserta didik kelas IV SDN 1 Panarung Tahun Pelajaran 2015/2016. Metode penelitian dalam penelitian ini kuantitatif korelasi. Hasil penelitian menunjukan bahwa ada perbedaan hasil belajar IPA dilihat dari penggunaan media konkret dengan media audio-visual pada peserta didik kelas IV SDN 1 Panarung Tahun Pelajaran 2015/2016. dengan hitungan uji t hitung sebesar 6,012 dan tabel sebesar 2,000 pada $\mathrm{N}=59$ dengan taraf signifikan $5 \%$ untuk 2 ekor yang artinya thitung $>$ tabel atau 6,012>2,000.

(C) Universitas Muhammadiyah Palangkaraya
\end{abstract}

Kata kunci: Hasil Belajar, IPA, Media Konkret, dan Media Audio-Visual

Desy $^{1}$ Universitas Muhammadiyah Palangkaraya

Diplan $^{2}$ Universitas Muhammadiyah Palangkaraya

ISSN: 2520-1923 


\section{PENDAHULUAN}

Pendidikan adalah usaha sadar dan terencana untuk mewujudkan suasana belajar dan proses pembelajaran agar peserta didik secara aktif mengembangkan potensi dirinya untuk memiliki kekuatan spritual keagamaan, pengendalian diri, kepribadian, kecerdasan, akhlak mulia, serta keterampilan yang diperlukan dirinya, masyarakat, bangsa dan negara sehingga dalam melaksanakan prinsip penyelenggaraan pendidikan harus sesuai dengan tujuan pendidikan nasional yaitu: mengembangkan kemampuan dan membentuk watak serta peradaban bangsa yang bermartabat dalam rangka mencerdaskan kehidupan bangsa, bertujuan untuk berkembangnya dan bertakwa kepada Tuhan yang Maha Esa, berakhlak mulia, sehat berilmu, calap, kreatif, mandiri dan menjadi warga negara yang demokratis serta bertanggungjawab.

Pendidikan sebagai suatu proses pertumbuhan dan perkembangan berarti suatu hasil interaksi seorang individu dengan lingkungannya baik fisik maupun sosial, mulai dari lahir sampai akhir hayatnya sebagai suatu proses dimana pewarisan sosial merupakan sebagian dari lingkungan sosial menjadi suatu alat yang dipergunakan untuk perkembangan dari pribadi- pribadi sebaik dan sebanyak mungkin. Mengembangkan kepribadian, kemampuan dan potensi pada diri peserta didik berlangsung melalui proses di dalam maupun di luar sekolah serta berlangsung seumur hidup.
Menurut Slameto (2010: 2) Pengertian secara psikologis, belajar merupakan "suatu proses perubahan yaitu perubahan tingkah laku sebagai hasil dari interaksi dengan lingkungannya dalam memenuhi kebutuhan hidupnya perubahanperubahan tersebut akan nyata dalam seluruh aspek tingkah laku".

Menurut Laksmini Antora dalam Trianto (2013:136) menyatakan bahwa "IPA adalah pengetahuan yang sitematis dan dirumuskan, yang berhubungan dengan gejala-gejala kebendaan didasarkan terutama atas pengematan dan dedukasi".

$$
\text { Hamalik, (2008: }
$$

mendefinisikan bahwa "Pembelajaran merupakan suatu proses penyampaian pengetahuan, yang dilaksanakan dengan menuangkan pengetahuan kepada siswa".

Hamidjojo dalam Arsyad (2013:4) memberi batasan bahwa "Media sebagai semua pihak bentuk perantara yang digunakan manusia untuk menyampaikan atau menyebarkan ide gagasan, atau pendapat yang dikemukakan itu sampai kepada penerima yang dituju"

Menurut Hamalik dalam Arsyad (2013:19) mengemukakan bahwa "Pemakaian media pembelajaran dalam proses belajar mengajar dapat membangkitkan keinginan dan minat yang baru, membangkitkan keinginan rangsangan kegiatan belajar dan bajkan membawa pengaruh-pengaruh psikologis terhadap siswa".

Menurut Jennah (2009: 25) ada beberapa prinsip pemilihan media pembelajaran yakni: 
1. Ia sudah merasa akrab dengan media itu

2. Ia merasa bahwa media yang dipilihnya dapat menggambarkan dengan lebih baik daripada dirinya sendiri

3. Media dipilihnya dapat menarik minat dan perhatian peserta didik.

Menurut Arsyad

(2013:91)

"Media Visual yang menggabungkan penggunaan secara memerlukan pekerjaan tambahan untuk memproduksinya. Salah satu pekerjaan yang diperlukan dalam media audiovisual adalah penulisan naskah dan storyboard yang memerlukan persiapan yang banyak, rancangan dan penulisan" Menurut Arsyad, (2009:22) media audio visual mempunyai kelebihan yaitu:

1. Film dapat menggambarkan suatu proses, misalnya proses pembuatan suatu keterampilan tangan dan sebagainya.

2. menimbulkan kesan ruang dan waktu.

3. Penggambarannya bersifat 3 dimensional.

4. Suara yang dihasilkan dapat menimbulkan realita pada gambar dalam bentuk ekspresi murni.

5. Dapat menyampaikan suara seorang ahli sekaligus melihat penampilannya.

6. Kalau film dan video tersebut berwarna akan dapat menambah realita objek yang diperagakan.

7. Dapat menggambarkan teori sain dan animasi.

\section{METODE PENELITIAN}

Menurut Purwanto (2010:238), "Penelitian ini menggunakan metode penelitian percobaan (eksperimen), metode ini dianggap paling sesuai dengan tujuan penelitian, yaitu dapat memfasilitasi kebutuhan penelitian untuk melihat hubungan sebab akibat dari suatu pembelajaran bagi peserta didik kelas IV".

Teknik pengumpulan data dapat dikatakan sebagai cara untuk mengumpulkan dalam melakukan penelitian untuk mengumpul data penelitian, maka teknik yang digunakan adalah observasi dan tes.

Dalam melakukan penelitian ini peneliti tidak hanya hadir pada saat jadwal mengajar, melainkan selalu aktif memantau dan meneliti peserta didik sekalipun diluar jam pelajaran guna memaksimalkan hasil penelitian.

Populasi penelitian disini adalah seluruh peserta didik di SDN-1 Panarung, SDN-2 Panarung, SDN-4 Panarung, dan SDN-5 Panarung Palangka Raya Tahun Pelajaran 2015/2016 yang berjumlah 170 peserta didik.

Populasi dibagi keadalam satuansatuan sampling yang besar yang disebut cluster. Berbeda dengan pembentukan strata, satuan sampling yang ada dalam tiap cluster harus relatif heterogen.

Langkah pengambilan sampel teknik random sampling yaitu Teknik klaster merupakan teknik memilih sampel lainnya dengan menggunakan prinsip probabilitas. Teknik ini mempunyai sedikit perbedaan dibandingkan kedua teknik yang telah dibahas sebelumnya. Teknik klaster atau Random Sampling ini memilih sampel bukan didasarkan pada individual, tetapi 
BITNET Jurnal Pendidikan Teknologi Informasi, Februari 2018, Volume 3 Nomor 1 (1-5)

http://journal.umpalangkaraya.ac.id/index.php/bitnet

lebih berdasarkan pada kelompok, daerah, atau kelompok subjek secara alami berkumpul bersama.

Menurut Hadjat dalam Purwanto (2010:241)"Populasi adalah kelompok besar individu yang mempunyai karakteristik umum yang sama".

\section{HASIL DAN PEMBAHASAN}

Pada tahap ini peneliti melaksanakan tindakan pembelajaran menggunakan Media Konkret Dengan Media Audio-Visual.

\section{Tabel 1}

Kategori Skor Pre Tes Kelas

Eksperimen I

\begin{tabular}{|l|l|c|l|l|}
\hline Ketentuan & Skor & F & Persentase & Kategori \\
\hline$<\mathrm{M}_{\mathrm{i}}-\mathrm{SB}_{\mathrm{i}}$ & $<45$ & 5 & $15,6 \%$ & Rendah \\
\hline $\begin{array}{l}\left.\mathrm{M}_{\mathrm{i}}-\mathrm{SB}_{\mathrm{i}}\right)- \\
\left(\mathrm{M}_{\mathrm{i}}+\mathrm{SB}_{\mathrm{i}}\right)\end{array}$ & 65 & 20 & $62,5 \%$ & Sedang \\
\hline$>\mathrm{M}_{\mathrm{i}}+\mathrm{SB}_{\mathrm{i}}$ & $>66$ & 7 & $21,9 \%$ & Tinggi \\
\hline \multicolumn{2}{|c|}{$\mathrm{Jumlah}^{2}$} & 32 & $100 \%$ & \\
\hline
\end{tabular}

\section{Gambar 1}

Grafik Skor Pre Tes Kelas Eksperimen I

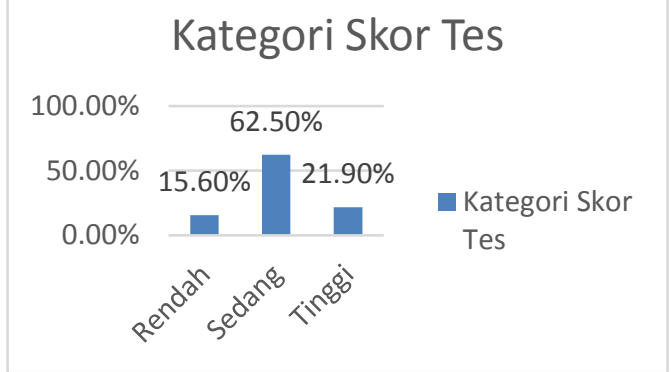

Dari tabel di atas maka diketahui sebanyak 5 orang peserta didik atau $15,6 \%$ dalam kategori rendah, 20 orang peserta didik atau $62,5 \%$ dalam kategori sedang, dan 7 orang peserta didik atau 21,9\% dalam kategori tinggi.
Tabel 2

Kategori Skor Pre Tes Kelas Eksperimen II

\begin{tabular}{|c|c|c|c|c|}
\hline $\begin{array}{c}\text { Ketentuan } \\
\text { Skor }\end{array}$ & Skor & $\mathbf{F}$ & $\begin{array}{c}\text { Persentas } \\
\mathbf{e}\end{array}$ & Kategori \\
\hline$<\mathrm{M}_{\mathrm{i}}-\mathrm{SB}_{\mathrm{i}}$ & $<61,9$ & 7 & $24,3 \%$ & Rendah \\
\hline $\begin{array}{c}\left(\mathrm{M}_{\mathrm{i}}-\mathrm{SB}_{\mathrm{i}}\right)- \\
\left(\mathrm{M}_{\mathrm{i}}+\mathrm{SB}_{\mathrm{i}}\right)\end{array}$ & $\begin{array}{c}61,9 \mathrm{~s} . \mathrm{d} \\
80,9\end{array}$ & 14 & $48,2 \%$ & Sedang \\
\hline$>\mathrm{M}_{\mathrm{i}}+\mathrm{SB}_{\mathrm{i}}$ & $>80,9$ & 8 & $27,5 \%$ & Tinggi \\
\hline \multicolumn{2}{|c|}{ Jumlah } & 29 & $100 \%$ & \\
\hline
\end{tabular}

\section{Gambar 2}

Grafik Skor Pre Tes Kelas Eksperimen I

\section{Kategori Tes}

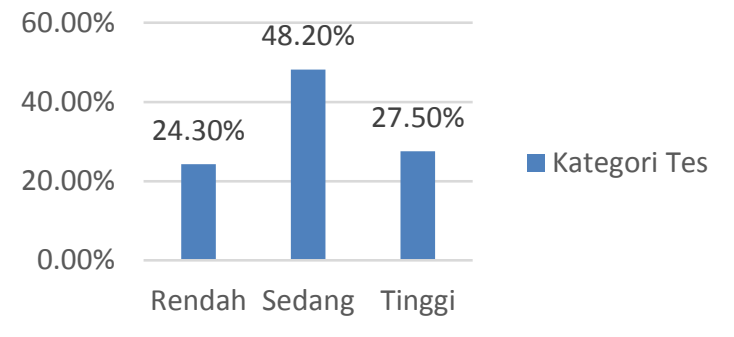

Dari tabel di atas maka diketahui sebanyak 7 orang peserta didik atau $24,3 \%$ dalam kategori rendah, 14 orang peserta didik atau 48,2 \% dalam kategori sedang, dan 8 orang peserta didik atau $27,5 \%$ dalam kategori tinggi.

\section{Tabel 3}

Kategori Hasil Skor Pos Tes Kelas Eksperimen I

\begin{tabular}{|l|l|c|l|l|}
\hline $\begin{array}{l}\text { Ketentuan } \\
\text { Skor }\end{array}$ & Skor & F & Persentase & Kategori \\
\hline$<\mathrm{M}_{\mathbf{i}}-\mathrm{SB}_{\mathbf{i}}$ & $<83,4$ & 2 & $6,3 \%$ & Rendah \\
\hline $\begin{array}{l}\left(\mathrm{M}_{\mathrm{i}}-\mathrm{SB}_{\mathbf{i}}\right) \\
-\left(\mathrm{M}_{\mathrm{i}}+\right.\end{array}$ & 83,4 s.d & 1 & $3,1 \%$ & Sedang \\
\hline $\mathrm{M}_{\mathbf{i}}+\mathrm{SB}_{\mathrm{i}}$ & $>91,6$ & 29 & $90,6 \%$ & Tinggi \\
\hline \multicolumn{2}{|c|}{$\mathrm{Jumlah}^{2}$} & 32 & $100 \%$ & \\
\hline
\end{tabular}


Gambar 3

Grafik Hasil Skor Pre Tes Kelas

Eksperimen I

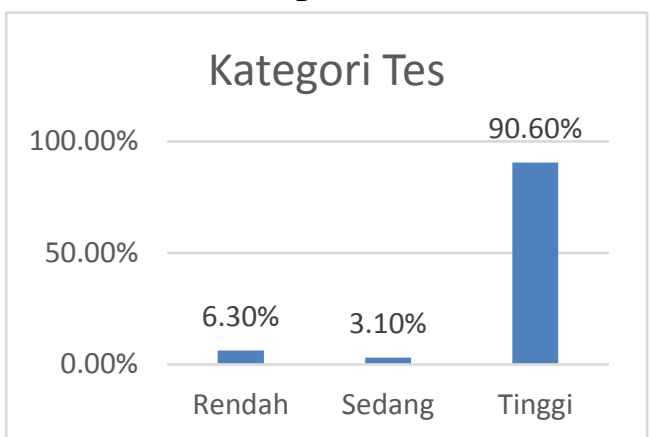

Dari tabel di atas maka diketahui sebanyak 2 orang peserta didik atau 6,3 $\%$ dalam kategori rendah, 1 orang peserta didik atau 3,1\% dalam kategori sedang, dan 29 orang peserta didik atau 90,6\% dalam kategori tinggi.

\section{KESIMPULAN}

Berdasarkan hasil penelitian yang telah dilakukan maka dapat disimpulkan bahwa ada perbedaan hasil belajar IPA dilihat dari penggunaan media konkret dengan media audio-visual pada peserta didik kelas IV SDN 1 Panarung Tahun Pelajaran 2015/2016. dengan hitungan uji thitung sebesar 6,012 dan tabel sebesar 2,000 pada $\mathrm{N}=59$ dengan taraf signifikan $5 \%$ untuk 2 ekor yang artinya thitung > tabel atau 6,012> 2,000 .

\section{DAFTAR PUSTAKA}

Azhar, Arsyad, 2013. Media Pembelajaran. Jakarta: PT. Rajagrafindo Persada

Hamalik, Oemar, 2008. Proses Belajar Mengajar. Jakarta: Bumi Askara

Jennah, Rodhatul, 2009. Media Pembelajaran. Banjarmasin: Atasari Press

Purwanto. 2010. Metodologi Penelitian Kuantitatif. Yogyakarta: Pustaka Belajar.

Slameto. 2010. Belajar dan Faktorfaktor yang Mempengaruhi Belajar. Jakarta: PT. Rineka Cipta.

Trianto. 2013. Model Pembelajaran Terpadu. Jakarta: PT. Bumi Aksara. 